\title{
Assessing Green Home Performance: A Case Study of Iskandar Malaysia
}

\author{
Tan, Teck Hong \\ Sunway University Business School, Sunway University, Malaysia \\ waltert@sunway.edu.my; waltertanth@gmail.com
}

\begin{abstract}
This paper reviews data from a survey to determine the satisfaction level of homeowners towards their residence in terms of green features in Iskandar Malaysia. In this survey, 295 copies of questionnaire forms were being distributed to green home owners and 116 forms were returned. Results show that homeowners are most satisfied with the green features of high ceiling, north-south orientation, double-glazed panel glass doors and windows, solar panel system and landscaped parks with facilities. Rain water harvesting system and low-flow water fixtures, on the other hand, are the least satisfied green features among homeowners. Greater knowledge of green home attributes that influence housing satisfaction could lead to better understanding and prediction of decision making in determining homeowners' needs.
\end{abstract}

Keywords: green home, customer satisfaction, housing satisfaction, Iskandar Malaysia

\subsection{INTRODUCTION}

Green homes generally take full advantage of the sun, wind and rainfall to help supply the energy and water needs of residents. With the government's latest move to encourage the adoption of energy-saving measures for residential properties, many green homes are built in the country (Green Building Index, 2013). In order to assess the performance of green homes, housing satisfaction has become the most commonly used in evaluating housing conditions and situations (Adriaanse, 2007; Erdogan et al., 2007; Lu, 1999). There have been several studies on housing satisfaction in Malaysia, and these studies are focused primarily on conventional homes. However, to date, less empirical studies has been conducted to appraise the performance of the quality of green homes in the country. It is interesting to note that green home attributes provided by housing developers may be necessary but are not appreciated by homebuyers. Therefore, this paper is to determine the performance of green homes by examining the relationship between green home attributes and homeowners' behaviors in terms of housing satisfaction. 


\subsection{LITERATURE REVIEW}

\subsection{Customer Satisfaction}

The objective measure of performance in terms of sales and revenues is the standard practice. In today's challenging environment, companies are also evaluating subjective measures. A range of subjective measures have been studies and found to have a relationship with objective measures. There are numerous studies found in the literature of subjective measures of performance using different measurement variables. However, customer satisfaction literature stands out when it involves subjective measures of performance.

Customer satisfaction is usually referred as a post-consumption of a product or service upon a judgment continuum that may range from dissatisfaction to satisfaction (Arora \& Singer, 2006). Customer satisfaction research has developed two types of evaluations, namely transaction-specific satisfaction and cumulative satisfaction. Transaction-specific perspective defines customer satisfaction as an emotional response by the consumer to the most recent transactional experience with an organisation (Oliver, 1993). In distinction, cumulative customer satisfaction is an overall customer satisfaction that is based on total purchase and consumption experiences with a product or service over a period of time (Anderson et al., 1994).

In evaluating housing situations and conditions, housing satisfaction has become the most widely used to determine the performance of homes ( $\mathrm{Lu}, 1999)$. The development of green homes requires continuous studies of housing satisfaction needs in order to examine homeowners' level with different types of green home features. Greater knowledge of green home features could lead to a better understanding and prediction in determining homeowners' needs. In this study, housing satisfaction has been used as an evaluative subjective measure for judging the success of green housing development constructed by a leading developer in the country. There have been different approaches to conceptualize housing satisfaction. In the purposive approach, housing satisfaction is conceptualised as a measure of the degree to which the environment facilitates or inhibits the goal of the user (Canter \& Rees, 1982). This approach, which is rooted in a cognitive view, emphasises goals or associated activities in relation to the attributes of the physical environment. For example, a household may live in a green home with the purpose of improving the quality of life as well as cost savings and if these intentions are met, it is possible that they could gain a high level of housing satisfaction.

However, households are not only goal-oriented but also value affective relations with the housing situation. The aspiration gap approach is the more common conceptual framework for housing satisfaction, describing housing satisfaction as being a comparison between households' actual and desired housing and neighborhood situations (Galster, 1987). This approach implies that if actual housing situations exceed desired situations, it will lead to housing satisfaction. On the other hand, if the actual housing situations do not meet with desired situations, it will lead to housing dissatisfaction. A high degree of congruence between actual and desired housing and neighborhood situations is an indication of a high rate of satisfaction because household's needs and aspirations are met by their housing conditions. The problem with this approach is to take expectation measurements (desired situations) before the product or service experience and perceived performance (actual situations) after the experience. However, Brown et al. (1993) suggested that a direct measure of performance would do more statistical justice. In this study, the direct measure method is adopted as many authors have used the direct effects method where only the customer's perception of the actual extent of customer satisfying rating is taken into account, which could eliminate the need to calculate the difference between actual and desired housing situations.

Based on previous literatures, there is little doubt that objective and subjective measures of housing attributes are significant factors of housing satisfaction (Amole, 2009; Lu, 1999; Roper et al., 2009; Tan, 2012b). Objective measures refer 
to the actual measurements, such as the presence, the lack of, or quantities of attributes while subjective measures refer to perception, emotions, attitudes and intentions towards the housing attributes. In this paper, only objective measures of green housing attributes are used to assess the performance of the quality of green homes.

\subsection{The Evolution of House Types in Malaysia}

Households' preferences are continuously transforming and this is well demonstrated by the evolution of houses styles in Malaysia, which will display households' preferences on house styles in Malaysia from past till present. House types such as terrace house, detached house, apartment and condominium are the evidence of continuing advancement to meet households' preferences. House types take account of the house form, roof form, decorative aspect, entire house component, design, building method and materiality (Ariffin \& Talib, 2008).

The evolution of house types in Malaysia began with Malaysia's vernacular house, particularly the 'suckling elephant house'. This is a type of conventional Malay house and it is also commonly known as a regional style of village house (Bahauddin \& Abdullah, 2008). The structure of this house is known by the shape of its roof whereby the formation of the main house is higher than the roof of the veranda. Thus, the structure is viewed alike to a calf (baby elephant) being fed by its mother (see Figure 1). In fact, traditional Malay houses are environmental-friendly and sustainable because these houses are in fundamental nature with post and beam constructions elevated on stilts, with gabled roof, penetrable walls and flooring. Furthermore, this type of house is generally constructed by the inhabitants of the community to fit with their socioeconomic, cultural and environmental needs (Jayapalasingam, 2009).

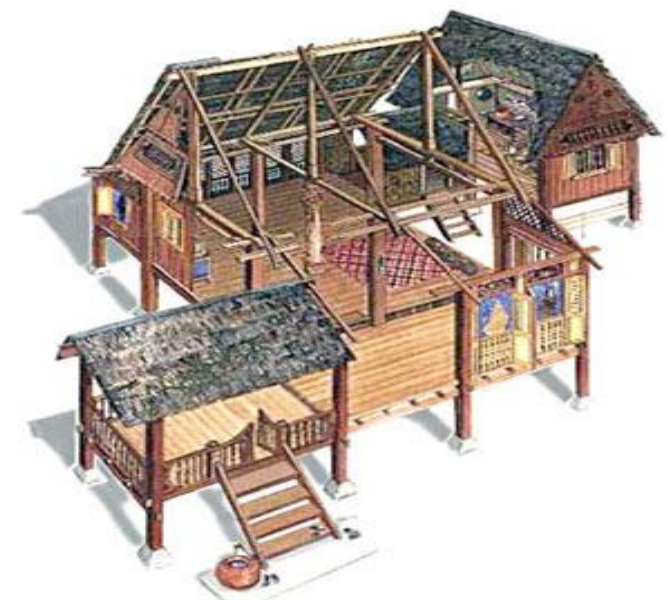

Figure 1: The "Suckling Elephant House"

Source: Chen (1998)

In the 1600s, the Spice Trade between the East and West encouraged more immigrants and traders from India, Arab, China, Persia, Indonesia and others to Malaya Peninsular. These people had brought in their culture and house-building techniques, for instance, immigrants and traders from Minangkabau, Sumatra bought in the shallow 'U' shaped curved roof or the 'Ruman Gadang' (Chen, 1998) (See Figure 2). During the Dutch occupation in the 1700s, townhouses or row houses were constructed in Malacca. Then, in the 1800s, during British involvement in the Malaya Peninsular, the Malayan bungalow, which was a combination of European and local elements, emerged such as the 'Bok House' (See Figure 3). In the 1900s, when British set up the Straits Settlements of Penang, Malacca and Singapore in 1826, new tin mines were opened in states 
like Perak and Selangor, which led to the development of small towns. Those laborers in the tin mines, mostly Chinese immigrants brought in their conventional house style and as a result, the two-storey shop houses were built (Chen, 1998).

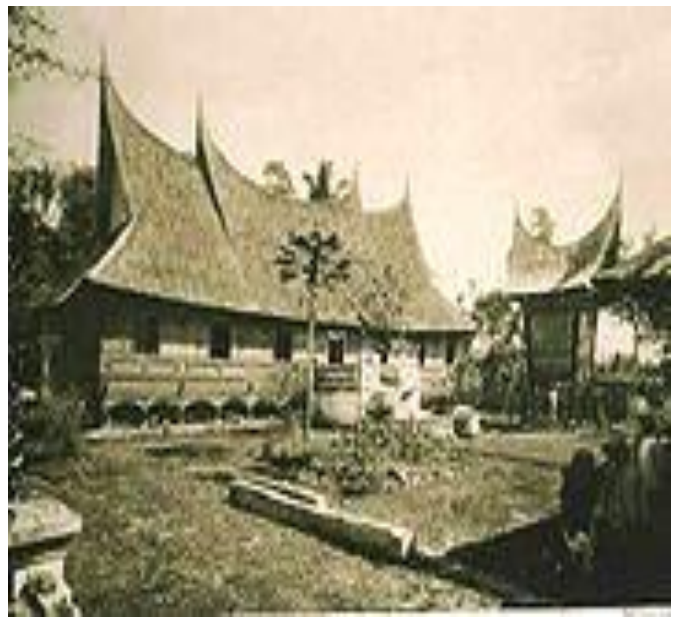

Figure 2: "Rumah Gadang"

Source: Great Asian Holiday (2010)

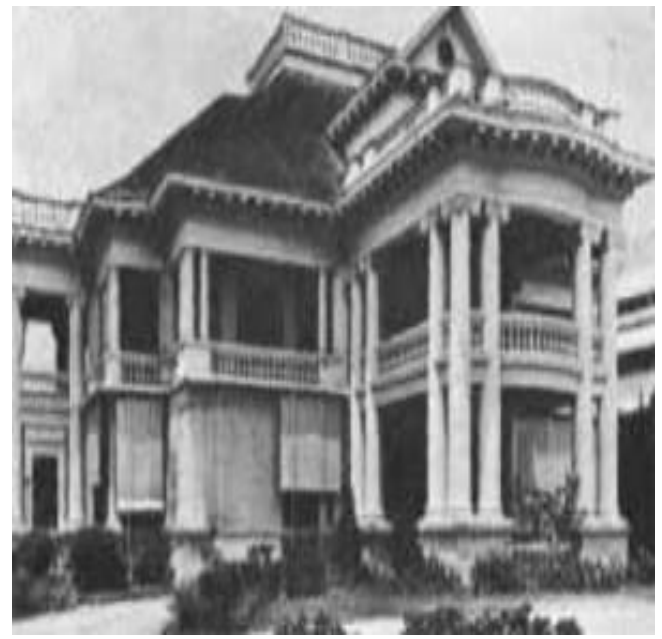

Figure 3:"Bok House"'

Source: Bowie (2004)

During the $20^{\text {th }}$ century, flats and condominiums, terrace houses, semi-detached and detached houses were introduced and these houses were inhabited by a great number of urban dwellers. The housing industry will continue evolving to suit the ever-changing households' preferences (Tan, 2008; Tan, 2012a). Recently, there is a growing interest in constructing houses that incorporate sustainable and green features (Green Building Index, 2013). Being a tropical country with abundant sun and rain and the prevailing southwesterly and northeasterly winds, there are many opportunities for developers in Malaysia to construct green homes.

Malaysian housing developers have chosen to certify their projects either with Singapore's Building and Construction Authority's Green Mark certification launced in 2005 or Malaysia’s Green Building Index (GBI), initiated by the Malaysia Institute of Architects (PAM) launched in 2009 to promote environmental awareness in the residential and commercial construction sectors. The construction industry is regarded as one of the major contributors to emision. In order to reduce the impact of buildings on the environment, there is a need to develop energy efficient homes. Furthermore, soaring energy prices over the last few years has increased the need for the real estate industry to participate in overall energy reduction through efficient housing construction and design.

\subsection{Green Home Features}

Green homes focus on energy and resource savings. Besides, their design takes into consideration the culture, traditions, local climate and environment (Edwards \& Naboni, 2013). This could be done through better sitting, design, construction, operation, maintenance and removal. Such homes are able to sustain and improve the quality of human life whilst maintaining the capacity of the ecosystem at local and global level.

Promotion of sustainable practice in real estate development has resulted in the development of various green strategies targeted at improving the environment and performance of the players in the industry. One of the examples is the use of solar panels. The solar panel works when the sunlight hitting silicon cells in a module generate a direct current. Solar power 
provides an endless supply of energy and energy derived from the sun is free to use. One major reason why solar power homes are becoming popular is because gas and oil prices keep rising. Besides, there will be no more air pollution caused by the conventional sources that supply electricity.

Commercial and household water consumption has been increasing steadily for the last century, and as the climate warms, other usages of water will increase. New ways will have to be found to reduce, reuse and retain water. Malaysia can no longer assume that there is an endless supply of water even in a country with high average rainfall per year. This is evident from the occasional water rationing as well as price increase of the municipal water supply. The solution to rationing and price increase would be rainwater harvesting and recycling. Collected and filtered rainwater could be used for general cleaning and watering plants. An experiment was conducted by the National Hydraulics Research Institute of Malaysia showing that reusing rainwater could contribute to 13, 650 liters of water saving per month per household.

Additionally, low-flow water fixtures could be installed in green homes to lessen the consumption of water. Low-flow water fixtures include water efficient tap fittings and sanitary appliances. Most people are aware that they can save water as much as 3,000 gallons a year by turning the tap when brushing their teeth and shaving, but most of us are not aware of products designed to save water when the tap is turned on. For example, a water-saving shower head works by limiting the output of water from a shower to be between 6 and 9 liter/minute, depending on the model used.

Most of the conventional building materials are made from concrete, steel and asphalt, known to retain heat in the building. Green home uses a design approach that enable minimum heat retention such as having a garden on a rooftop and planting more trees surrounding the compound of the house. Furthermore, the use of recycled industrial goods including recycled stones and tiles could help to minimise waste and maximise reuse that contributes towards having green homes.

In summary, green homes are constructed with the following green features and characteristics in order to reduce the residential sector's impact on climate change:

- Installation of rainwater harvesting system for irrigating plants

- Use of low carbon-emitting construction materials, such as low volatile organic compound (VOC) paints, recycled content wall and floor tiles

- Use of solar roof shingles to generate renewable energy

- Double-glazed glass panels to reduce heat transmission

- Use of low-flow water features such as water efficient sanitary appliances and tap fittings

- Lush and landscaped greenery with water features (pond)

- Equip with energy efficiency appliances such as LED lights, and air conditioning system

\subsection{Its Advantages and Disadvantages}

There is a rising attention in the physical structure of environmental-friendly buildings (Eicholtz et al., 2008; Furst \& McAllister, 2011). This is because the built environment accounts for an estimated $30 \%$ of the total primary energy utilisation and greenhouse gas emission worldwide (Bond, 2010). As pointed by Feliciano and Prosperi (2011), a major share of GHG emission from the building sector could be due to fast and cheap construction practices without making use of energy-efficient measures and renewable energies. There has been a growing focus on energy efficient construction methods in the built environment. In the past, developers have relied on conventional processes in constructing buildings. However, these processes are unsustainable in the long run. Therefore, sustainable features in constructing buildings are an important contributor to achieve sustainable development and practices. Environmentally sustainable buildings normally have low carbon footprints, 
which is particularly important in the construction industry as this industry is a major consumer of raw materials (Lovell, 2004; Feliciano \& Prosperi, 2011).

Several studies have demonstrated the financial advantages of green buildings both for residential and commercial buildings. The most frequently cited financial benefits of green building are the increase in occupancy rate and rental value as well as the property price (Furst \& McAllister, 2009; Miller et al., 2008; Pitts \& Jackson, 2008; Yu \& Tu, 2011). Additionally, green buildings generally use key resources like energy and water more efficiently than traditional buildings, which could result in savings in utilities bills (Ling \& Gunawansa, 2011). These externalities have contributed to the overall reputation of the property.

The most important benefit of green building is not only confined to the environment, but includes the wellbeing of a person from the perspective of health. There is a growing number of studies that demonstrate the correlations between improvement in indoor air quality, better lighting and building comfort, worker health and productivity (Fisk \& Rosenfeld, 1997; Miller et al., 2008). Improvement of indoor air quality could help in reducing sick building syndrome which consequently result in reduced sick leave and absenteeism. As a result, corporate tenants are attracted to green building as compare to the other nearby buildings that do not have these green features.

Although having green building is said to have many advantages, there is literature which presents conflicting evidence on the benefits of green buildings. The differences may be underpinned by the alternative explanations. For example, sampling methodology and measurement may have contributed to the conflicting results (Muldavin, 2008). Also, some of the end users may not appreciate the green features provided by the developer. A garden on rooftop might be a matter of concern for building owners fear water leakage if the water proofing membrane malfunctions.

The price of a green building may be more than that of a conventional building. According to $\mathrm{Yu}$ and $\mathrm{Tu}$ (2011), the price differences between green and non-green buildings are cost driven rather than market driven. This implies that developers have transferred the green costs into their asking prices as they need to cover the additional costs incurred for implementing green features and complying green standard in order to make these homes more popular among the home buyers.

\subsection{METHODS}

While there is a limited number of studies of green homes in Malaysia to provide a case study, this paper focuses on 295 green houses developed by one of the leading developers by examining responses to the variation between the expectations and realities of key green home attributes as experienced by homeowners who reside in their green homes for at least six (6) months in Iskandar Malaysia. Iskandar Malaysia is suited for the purpose of this study because it is Malaysia's proposed model of a socio-economically and environmentally sustainable development zone with excellent connectivity, infrastructure services, and environmental sensitivity (Rizzo \& Glasson, 2012).

In this survey, only semi-detached and detached houses in these townships were considered for this study. Reason being that the Malaysian government has recently mandated that builders of semi-detached and detached houses to put in place energy efficiency features, such as rainwater harvesting system ( $\mathrm{Ng}, 2011)$. Of the questionnaire, 295 sets were hand-delivered, and 116 responses ( 40 percent response rate) were received. 
In order to determine the effects of green home attributes on housing satisfaction, regression analysis was performed. The outcome variable in the analysis was housing satisfaction. It has been common, in measuring housing satisfaction to use an index or highly correlated items rather than a single-item variable. Following Tan (2012b) and Tan (2013), the construct of housing satisfaction was measured using an index based on four questions (alpha $=0.892$ ) which were: "I am satisfied with living here in general", "I do not intend to move to another type of housing in the near future", "I will recommend my friends/relatives to move into my neighborhood" and "I intend to buy another property in the same neighborhood". Responses were scored on a five-point scale of 1 (strongly disagreed) to 5 (strongly agreed). Furthermore, respondents were asked to express the extent to which they are satisfied or dissatisfied with different types of green features using a dichotomous scale (1 $=$ yes; $0=$ no). In-depth interviews were also conducted to ascertain the expectations of respondents from their green homes and to discuss issues in relation to green home attributes. The degree of housing satisfaction may tend to vary by life cycle attributes, such as gender, marital status and education background. In this study, these variables are controlled to identify the green home attributes that are significant in influencing green housing satisfaction. Given the preceding discussion, the research question of this paper is as follows:

To what extent do the importance of green home attributes relate significantly to housing satisfaction after controlling for socio-demographic characteristics of green home owners?

In this study, two regression equations were examined. The first equation was to assess the effect of green home attributes on the satisfaction level of green home and the second one was to examine whether green home attributes predict housing satisfaction after controlling for differences in socio-demographic characteristics of respondents, such as gender, marital status and education background. The multiple regression equations have the following form:

(1): $\mathrm{HS}=\mathrm{a}+\beta_{1} \mathrm{~W}+\beta_{2} \mathrm{NS}+\beta_{3} \mathrm{LF}+\beta_{4} \mathrm{GP}+\beta_{5} \mathrm{ES}+\beta_{6} \mathrm{RW}+\beta_{7} \mathrm{RT}+\beta_{8} \mathrm{HC}+\beta_{9} \mathrm{LG}+\beta_{10} \mathrm{SP}+\epsilon$

(2) $\mathrm{HS}=\mathrm{a}+\beta_{1} \mathrm{~W}+\beta_{2} \mathrm{NS}+\beta_{3} \mathrm{LF}+\beta_{4} \mathrm{GP}+\beta_{5} \mathrm{ES}+\beta_{6} \mathrm{RW}+\beta_{7} \mathrm{RT}+\beta_{8} \mathrm{HC}+\beta_{9} \mathrm{LG}+\beta_{10} \mathrm{SP}+\beta_{11} \mathrm{D}+\epsilon$

where HS = housing satisfaction; $\mathrm{W}$ = water features in the neighbourhood; NS = north-south orientation; LF = low-flow water features; $\mathrm{GP}=$ double-glazed panel glass; $\mathrm{ES}=$ energy saving appliances; $\mathrm{RW}=$ rainwater harvesting; $\mathrm{RT}=$ recycled content tiles; $\mathrm{HC}=$ high-ceiling; $\mathrm{LG}=$ landscaped greenery; $\mathrm{SP}=$ solar panel system; and $\mathrm{D}=$ demographic descriptors.

\subsection{RESULTS AND DISCUSSION}

\subsection{Satisfaction level of Green Features}

As shown in Table 1, the Adjusted $\mathrm{R}^{2}$ values of the first and second regression equations explained about $73.6 \%$ and $75.1 \%$ of variation in the level of housing satisfaction, respectively. There was not much difference in the explanatory power of two models, indicating green features influenced more strongly than socio-demographic characteristics. However, only the results in the second model were emphasised and examined in details in the following analysis.

From the study, it seems that respondents are interested in the experiences they can get from consuming the product. The following tables were to show the satisfaction level of the respondents in Iskandar Malaysia based on specific green features of the property (Table 1). 
Table 1: Regression Analysis

\begin{tabular}{|c|c|c|c|c|}
\hline & \multicolumn{2}{|c|}{ Model 1} & \multicolumn{2}{|c|}{ Model 2} \\
\hline & B & $\mathrm{t}$ & B & $\mathrm{t}$ \\
\hline Constant & $\begin{array}{c}2.619 * * \\
(0.103)\end{array}$ & 25.392 & $\begin{array}{c}2.259 * * \\
(0.154)\end{array}$ & 14.675 \\
\hline Water features in the neighborhood & $\begin{array}{c}0.233 * * \\
(0.081)\end{array}$ & 2.886 & $\begin{array}{c}0.213 * * \\
(0.079)\end{array}$ & 2.698 \\
\hline North-south orientation & $\begin{array}{c}0.383 * * \\
(0.071)\end{array}$ & 5.360 & $\begin{array}{c}0.389 * * \\
(0.070)\end{array}$ & 5.544 \\
\hline Low-flow water features & $\begin{array}{c}0.037 \\
(0.085)\end{array}$ & 0.436 & $\begin{array}{c}0.118 \\
(0.087)\end{array}$ & 1.355 \\
\hline Double-glazed panel glass & $\begin{array}{c}0.179 * * \\
(0.063) \\
\end{array}$ & 2.825 & $\begin{array}{l}0.127 * \\
(0.066) \\
\end{array}$ & 1.923 \\
\hline Energy saving appliances & $\begin{array}{c}0.102 \\
(0.065)\end{array}$ & 1.578 & $\begin{array}{c}0.093 \\
(0.069)\end{array}$ & 1.358 \\
\hline Rainwater harvesting & $\begin{array}{c}0.082 \\
(0.064)\end{array}$ & 1.274 & $\begin{array}{c}0.047 \\
(0.067)\end{array}$ & 0.706 \\
\hline Recycled content tiles & $\begin{array}{c}0.013 \\
(0.065)\end{array}$ & 0.192 & $\begin{array}{c}0.064 \\
(0.067)\end{array}$ & 0.960 \\
\hline High ceiling & $\begin{array}{c}0.477 * * \\
(0.072)\end{array}$ & 6.648 & $\begin{array}{c}0.477 * * \\
(0.074)\end{array}$ & 6.480 \\
\hline Landscaped greenery & $\begin{array}{c}0.290 * * \\
(0.059) \\
\end{array}$ & 4.904 & $\begin{array}{c}0.257 * * \\
(0.060) \\
\end{array}$ & 4.319 \\
\hline Solar panel system & $\begin{array}{c}0.255^{* *} \\
(0.069) \\
\end{array}$ & 3.688 & $\begin{array}{c}0.271 * * \\
(0.068) \\
\end{array}$ & 3.965 \\
\hline \multicolumn{5}{|l|}{ Primary education (ref) } \\
\hline Secondary education & & & $\begin{array}{c}0.302 * * \\
(0.105)\end{array}$ & 2.876 \\
\hline Tertiary education & & & $\begin{array}{c}0.319 * * \\
(0.112) \\
\end{array}$ & 2.858 \\
\hline Males & & & $\begin{array}{c}0.066 \\
(0.060) \\
\end{array}$ & 1.093 \\
\hline Married & & & $\begin{array}{c}0.070 \\
(0.089) \\
\end{array}$ & 0.784 \\
\hline $\mathrm{R}^{2}$ & 0.759 & & 0.782 & \\
\hline Adjusted $\mathrm{R}^{2}$ & 0.736 & & 0.751 & \\
\hline Std error of estimate & 0.28056 & & 0.27205 & \\
\hline Durbin-Watson & 1.095 & & 1.083 & \\
\hline
\end{tabular}

** Significance at the 0.01 level; Significance at the 0.05 level

Figures in parenthesis are standard errors.

The results in Table 1 revealed that all other thing being equal, high ceiling $(\beta=0.477)$, north-south house orientation $(\beta=0.389)$, lush and landscaped greenery $(\beta=0.257)$, solar panel system $(\beta=0.271)$, and water features in the neighborhood $(\beta=0.213)$ were statistically significant related to housing satisfaction at the 0.01 level. However, double-glazed panel glass door and window $(\beta=0.127)$ was only statistically significant at the 0.05 level.

In this survey, respondents generally satisfied with green features to improve indoor air quality such as high ceiling and north-south house orientation. Respondents generally agreed that high ceiling homes allow cross ventilation for a cooling ambience. Also, homes oriented in the north-south position could reduce heat by minimizing direct sunlight into the house. The results also implied that respondents prefer to live in a home with lush and landscaped greenery as the trees and shrubs 
surrounding the residential development could serve as the natural shades to cool down the house and reduce the need for cooling systems. There is also evidence that respondents were more likely to use solar panels to capture and store the heat from the sun. Solar power would appear to be a good source of renewable energy for Malaysia as the country is bathed in sunlight. It has been found that a high level of satisfaction was reported for respondents who reside in the green neighborhood with water features. Lastly, respondents generally were satisfied with double-glazed glass door and window due to the fact that the usage of electricity could be reduced as glass door and window are being used to reduce heat transmission and take advantage of daylight.

Rainwater tanks are installed in this housing development to capitalise on nature's offering by collecting rainwater from the sloping rooftop for irrigating plants and vegetation. However, respondents in the survey were not satisfied with the rainwater harvesting system that uses recycled water for watering plants even though this could result in a significant reduction of water consumption. These viewpoints are supported from the in-depth interview with few respondents in describing the practicality of using the rainwater harvesting system. One respondent in the interview explained: "The water collected is so dirty that I cannot use to flush the toilets and irrigate the garden". Echoing these sentiments another respondent said: "It is a good system but its practicality needs some work". He added further: "The storage tank will dry out when there is no rain for a week." Judging from the mixed responses to this system, it seems that much has to be done with regard to increasing the practicality of this system. It appears that there is a need to improve the quality of the rainwater filter collector which could effectively separate the water from leaves and other debris.

According to this survey, it showed that low-flow water fixtures could not function as good as the normal high-flow water fixtures. Low-flow water fixture is a water efficient fitting to reduce water usage by reducing the flow of water such as water-efficient sanitary appliances, but respondents generally complain about these low flow water features supplied by the developer. As few respondents pointed out: "We need long waiting time to fill up a bottle of water". Also, respondents in the survey were not satisfied with wall and floor tiles that use recycled materials and energy saving appliances. From the above findings, it would seem that marketing a green home is not without its share of challenges. Housing developers are required to carry out continuously long-term engagement programs to promote and raise awareness about environmentally friendly home features.

Of socio-demographic characteristics, only education was statistically significantly related to housing satisfaction when controlled for all other factors. In line with previous studies, more highly educated households might be more likely to pay for environmentally sensitive products. In terms of marital status and gender, these two demographic descriptors appear to be insignificant factors in explaining housing satisfaction.

\subsection{CONCLUSIONS \& RECOMMENDATION}

There has been increasing media reporting of issues relating to green homes recently. The focus point of green home is to improve the efficiency of resource use, at the same time reduce the building's impact on the environment during the building's lifecycle (Bond, 2010). Housing developers are advised to construct homes that include energy efficient measures because of the impact of the built environment on climate change. However we do not know which green features are preferable by green homeowners. Therefore, this research intends to fill the gap by determining the extent to which homeowners are satisfied with different types of green features and revealing the green features that homeowners are not satisfied with. Based on the survey, respondents are satisfied with features that bring about energy efficiency, environmental protection and better indoor environmental quality, such as high ceiling, north-south orientation, solar panel system, doubleglazed glass panel and lush and landscaped parks with water features. 
It appears that homebuyers are conscious of what they are buying and they also insist on the house design that is efficient in energy consumption. The support from homebuyers is a clear indication that the demand for green homes is here to stay. In order to guide the local property industry towards becoming more environment-friendly, there is a need to call for a joint effort of the different stakeholders that come into play from the designers to the architects, engineers, government and developers to support the green building rating tools (Green Building Index - GBI) that are developed locally for local conditions.

The GBI in Malaysia, having been introduced for the past 4 years, has yet to gain extensive interest and response from the general public as well as housing developers. One way to demonstrate on-going commitment at government level to the GBI that are developed locally for local conditions is to provide more incentives, such as subsidies to mall developers for the adoption of the GBI. These incentives come in the form of tax exemption for building owners that achieve GBI certification. Subsidies should be given out as going green is not as affordable as it seems. Certain examples of subsidies are solar panel subsidies; water saving subsidies, and so on. These subsidies could be designed for housing developers to develop their ecofriendly credibility as financial incentives are identified as major motivational factor to encourage builder to go beyond the minimum requirement under the rating system (Raisbeck \& Wardlaw, 2009). As for incentives to homebuyers, the government should consider either giving more price discount or stamp duty exemption for homebuyers of properties with green features.

Homeowners in this study are not generally satisfied with the rainwater harvesting system, low flow water fixtures, some energy saving appliances and recycled ceramic titles. As such, the housing developers should continue to contribute to the green efforts by creating throughout information and education that put genuine green thoughts into the design such as, rainwater harvesting system and low-flow water fixtures to increase housing satisfaction of homeowners.

\subsection{ACKNOWLEDGEMENT}

I would like to thank Mr. Ling Ten Heng for his kind assistance in completing this project.

\subsection{REFERENCES}

Adriaanse, C. C. M. (2007). Measuring residential satisfaction: A residential environmental satisfaction scale (RESS). Journal of Housing and the Build Environment, 22,287 - 304.

Amole, D. (2009). Residential satisfaction in student housing. Journal of Environmental Psychology, 29, 76 - 85.

Anderson, E. W., Fornell, C., \& Lehmann, D. R. (1994). Customer satisfaction, market share, and profitability: Finding from Sweden. Journal of Marketing, 58(3), 53 - 66.

Ariffin, M., \& Talib, A. (2008). Perak Malay (Kutai) architecture: A methodological approach in extensive survey and analysis. $3^{\text {rd }}$ International Qualitative Research Convention, UniversitiTeknologi Malaysia and Qualitative Research Association of Malaysia.

Arora, R., \& Singer, J. (2006). Customer satisfaction and value as drivers of business success for fine dining restaurant. Services Marketing Quarterly, 28(1), 89 - 102.

Bahauddin, A., \& Abdullah A. (2008). Sustainable design of the suckling elephant house of Malaysia. Proceeding of Ecocity World Summit 2008.Universiti Sains Malaysia.

Bond, S. (2010). Lessons from the leaders of green designed commercial building in Australia. Pacific Rim Property Research Journal, 16(3), 314 - 338.

Bowie, P. (2004). Buletins Warisan, Special Edition December 2004. Retrieved October 10, 2012, from Badan Warisan Malaysia website: http://www.badanwarisan.org.my/buletins/dec04.pdf 
Brown, T. J., Churchill, G. A., \& Peter, J. P. (1993). Improving the measurement of service quality. Journal of Retailing, 69(1), 127 - 139.

Canter, D., \& Rees, K. (1982). A multivariate model of housing satisfaction. International Review of Applied Psychology, 31, 185-208.

Chen, V. F. (1998). The encyclopedia of Malaysia: Architecture. Singapore, Archipelago Press.

Edwards, B. W., \& Naboni, E. (2013). Green buildings pay: Design, productivity and ecology. New York: Routledge.

Eicholtz, P., Kok, N., \& Quigley, J. (2008). Doing well by doing good? Green office buildings. Working Paper, Fisher Centre for Real Estate and Urban Economics, University of California, Berkeley.

Erdogan, N., Akyol, A., Ataman, B., \& Dokmeci, V. (2007). Comparison of urban housing satisfaction in modern and traditional neighborhoods in Edirne, Turkey. Social Indicators Research, 81, 127 - 148.

Feliciano, M., \& Prosperi, D. C. (2011). Planning for low carbon cities: Reflection on the case of Broward County, Florida, USA. Cities, 28, $505-516$

Fisk, W. J., \& Rosenfeld, A. H. (1997). Estimates of improved productivity and health from better indoor environment. Indoor Air, 7, $158-172$.

Furst, F., \& McAllister, P. (2009). An investigation of the effect of eco-labeling on office occupancy rates. Journal of Sustainable Real Estate, 1(1), 49- 64.

Furst, F., \& McAllister, P. (2011).Green noise or green value? Measuring the effects of environmental certification on office values. Real Estate Economics, 39, 45 - 69.

Galster, G. (1987). Identifying the correlates of dwelling satisfaction: An empirical critique.Environment and Behavior, 19(5), $539-568$.

Great Asia Holiday. (2010) Indonesia: Rumah Gadang. Retrieved October 10, 2011, from Destinations website: http://greatasiaholiday.com/west_sumetera_minangkabau_rumahgadang.html

Green Building Index. (2013). Residential New Construction (RNC) - Certified Building. Retrieved January 19, 2013 from Green Building Index website: http://www.greenbuildingindex.org/organisation-certified-buildings-NRNC.html>.

Jayapalasingam, S. (2009). Malaysia's terraced housing: Towards an environmentally sustainable future. Master Thesis. Deakin University.

Ling, F. Y. Y., \& Gunawansa, A. (2011). Strategies for potential owners in Singapore to own environmentally sustainable homes. Engineering, Construction and Architectural Management, 18(6), 570 - 594

Lovell, H. (2004). Framing sustainable housing as a solution to climate change. Journal of Environmental Policy and Planning, 6(1), 35 - 55.

Lu, M. (1999). Determinants of residential satisfaction: Ordered logit vs. regression models. Growth and Change, 30, $264-$ 287.

Miller, N., Spivey, J., \&Florance, A. (2008). Does green pay off. Journal of Sustainable Real Estate, 8(2), 91 - 103.

Muldavin, S. (2008). Quantifying 'green'value: Assessing the applicability of the CoStar studies. Green Building Finance Consortium, California.

Ng, C. Y. (2011). New bungalows, semi-detached homes, government buildings must have rain water system. The Star, June 13.

Oliver, R. L. (1993). Cognitive, affective and attribute bases of the satisfaction response. Journal of Consumer Research, $20(3), 418-430$.

Pitts, J., \& Jackson, T. O. (2008). Green buildings: Valuation issues and perspectives. Appraisal Journal, Spring, 115 -118

Raisebeck, P., \&Wardlaw, S. (2009). Considering client-driven sustainability in residential housing. International Journal of Housing Market and Analysis, 2(4), 318 - 333.

Rizzo, A., \& Glasson, J. (2012). Iskandar Malaysia. Cities, 29(6), 417 - 427. 
Roper, A., Voler, B., \& Flap.H. (2009). Social network and getting a home: Do contacts matter? Social Networks, 31 , 40 51.

Tan, T. H. (2008). Determinants of homeownership in Malaysia. Habitat International, 32, 318 - 335.

Tan, T. H. (2012a). Meeting first-time buyers' housing needs and preferences in Greater Kuala Lumpur. Cities, 29(6), 389 396.

Tan, T. H. (2012b). Housing satisfaction in medium- and high-cost housing: The case of greater Kuala Lumpur. Habitat International, 36(1), $108-116$.

Tan, T. H. (2013). Determinants of intention to inhabit eco-friendly homes in Malaysia. Journal of Green Building, 8(4) (In Press).

Yu, S. M., \& Tu (2011). Are green buildings worth more because they cost move? Institute of Real Estate Studies (IRES) Working paper series. IRES2011-023, National University of Singapore. 